\title{
The Status of Hindu Women from Antiquity to (Early) Modernity: A Downward Graph

\author{
Sadia Afrin
}

\begin{abstract}
The main purpose of this research paper is to acquire an understanding of the continuously changing status of Hindu women from antiquity (Prevedic era, c1500-1100BCE) to modernity (Early Modern Era, 18th Century). In my paper I will try to establish my point that the Hindu religion, which is seen today to subdue women the most, once esteemed them highly and with the passing centuries gradually their status degraded. Therefore the fluctuating status of Hindu women resembles a downward graph. The methodology will be historical method of qualitative research. As Primary source I will take resort to Hindu Core Scriptures (both Sruti \& Smriti) and for secondary source will receive help from historical records, books, journals, reports and websites.
\end{abstract}

Keywords: Brahmavadinis, Sadyodvahas, Sati, Smriti, Sruti, Upadhayanis, Upadhayayas

\section{I.INTRODUCTION}

Hinduism perhaps the oldest of all living religions, has neither any definite date of origin nor any definite founder associated with it. As it is called the Sanatana Dharma, a religion coming down to people through eternity. Hinduism has over 1.2 billion adherents worldwide (15\% of world's population) (Global Religious Composition, 2012). Majority population resides in South Asian countries like India, Nepal and Bangladesh. After Muslims, Hindu people consist the second largest population in our country. Under the umbrella of Hinduism, discussion of any particular concept will cover a huge sphere, starting from prehistoric era, the discussion of the status of Hindu women exerts no difference. Browsing through the Hindu scriptures we can see a pattern. Hindu scriptures, particularly of the earlier period, place great value on the contributions of woman. The much-reported abuses of woman in Subcontinent demonstrate a falling away from traditional practice. Hindu women of Prevedic and Vedic age enjoyed an elevated status but from the beginning of the Christian era women held an inferior position in relation to man. By the passing centuries the status of Hindu women saw nothing but degradation. Last millennium saw that, the placing of women in the social structure was not as par with its' male counterpart. The status of Hindu woman reached to its alltime low during the late medieval and early modern period. Therefore the hypothesis of my research is that the fluctuating status of Hindu woman from antiquity to early modernity resembles a downward graph.

Manuscript received on March 08, 2021.

Revised Manuscript received on March 13, 2021.

Manuscript published on March 30, 2021.

* Correspondence Author

Sadia Afrin*, Department of World Religions and Culture, University of Dhaka

(C) The Authors. Published by Blue Eyes Intelligence Engineering and Sciences Publication (BEIESP). This is an open access article under the CC BY-NC-ND license (http://creativecommons.org/licenses/by-nc-nd/4.0/)

\section{II.THE STATUS OF HINDU WOMEN}

The discussion of the status of women will begin from a very early prehistoric period. As we don't have many firsthand sources of that time other than Hindu core scriptures, I will frequently take resort to them. For later periods I will seek help from a number of books, journals, reports and websites. The authoritative Hindu Scriptures have been divided into two broad categories: Sruti (Primary Scriptures) and Smriti (Secondary Scriptures).

Sruti in Sanskrit means "that which is heard." Thus the Sruti scriptures are the eternal truths that the Vedic seers, called rishis', are said to have heard in their deep meditations. These scriptures are not considered the works of the human mind, but an expression of what has been realized through intuitive perception. This category includes the four Vedic Samhitas (Rig, Sama, Yajur and Atharva), the Brahmanas, the Upanishads and the Aranyakas.

Smriti in Sanskrit means "that which is remembered." Smriti scriptures are considered to be of human origin and include a large number of religious writings, such as the Epics (Ramayana, Mahabharatta), the Puranas, and Dharma Shastras (ManuSmriti, YajnavalkyaSmriti). Smriti scriptures are the secondary scriptures of Hinduism and are composition of a later period. (Tiwari, 1987)

Browsing through the Hindu scriptures we can see a pattern. Hindu scriptures, particularly of the earlier period, place great value on the contributions of woman. The muchreported abuses of woman in Subcontinent demonstrate a falling away from traditional practice. Hinduism is one of the few living religions where female goddesses are worshipped. Early Hindu scriptures show emphasize on the worship of mother goddesses. And the authority of male high gods is the context of a later period. Where Sruti scriptures emphasize on the worship of mother goddess, for Smriti scriptures it is about male gods. It must be noted here that Hindu Scripture are not directly revealed words from God, they are revealed but through mediums (rishis'). Many Hindu scholars hold a view that Hindu scriptures, mainly later ones have been corrupted by the coloring of human mind. References from both Sruti and Smriti will be accounted here, in order to give a clear idea of the spheres of life of Hindu women; such as educational, political, social, economic etc. An intriguing study of historical accounts points out that, from the beginning of the Christian era women held an inferior position in relation to man. By the passing centuries the status of Hindu women saw nothing but degradation.

Published By:
Eyes Intelligence Engineering

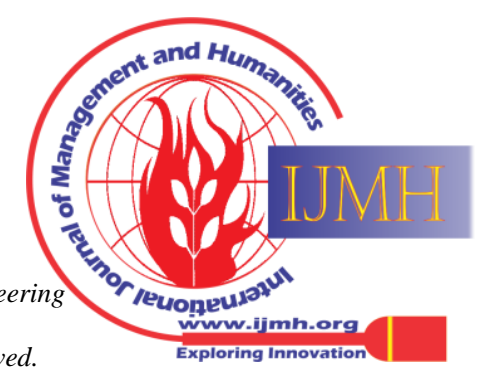




\section{The Status of Hindu Women from Antiquity to (Early) Modernity: A Downward Graph}

Last millennium saw that, the placing of women in the social structure was not as par with its' male counterpart. Having no rights, she cannot move nor can she do anything at her own will. Historical accounts tell us that, condition was not always the same; the Hindu religion, which is seen today to subdue women the most, once esteemed women highly. Hindu Sruti scriptures placed women to a position of respect and power. Though not like Sruti, Smriti writers' respected women. A chronological survey of the Vedic literatures, the Epics, the Puranas and the Dharmasastras reveals that the position of women declined with the corresponding era. There has been a misconception that Hindu scriptures only subdued and humiliated women more than any living religion. While female infanticide and female foeticide (the act of aborting a foetus because it is female) are heinous practices of today's Hindu society in Punjab and other regions in India; there is no reference to this evil custom in the Vedic, Epic or Classical literature. If female infanticide had at all been practiced, it must have been confined to a very small section of society, otherwise Smriti writers would have mentioned it somewhere. While going through the civilizations we can decipher that the further back we go into antiquity, the general position of woman gets more and more unsatisfactory. In this respect Indus Valley Civilization is quite unique, since here we can find an overwhelming exception to the general rule. The much discussed discovery of the female 'Clay Figurine' in the Indus Valley Civilization bears the mark of the fact that how highlighted the social and cultural role of women has been during that time. Additionally the discovery of bronze 'Dancing Girl' figurines points out the specific social actions played by women during that time. Hence the further back we go, the position of women gets more satisfactory in spheres like; such as educational, social, economic, political etc. According to M L Goel "Women were held in higher respect in India than in other ancient countries, and the Epics and old literature of India assign a higher position to them than the epics and literature of ancient Greece." (Goel, 2018) Scholars of different faiths agree upon the fact that in ancient Hindu society women received quite an honored position. In Upanishads we can find ample evidences of free conversation of women with man upon various philosophical topics. Woman during that time received education, could voice her opinion in political or social matters and was free to choose her own husband.

By the end of Vedic era the condition of women started to deteriorate. The freedom once received by woman was curtailed slowly and she no longer had a say even in her family. Polygamy in upper-class male began to be the way along with female child marriage. Dowry system came into vogue, a man of eighty could easily marry a teenager girl as he will demand less dowry, and therefore she was destined for early widowhood. Widow Remarriage got prohibited and Sati, the custom of widow lying in her dead husband's pyre, came into vogue. Day by day daughters were seen as the cause of pain and despair for a father, therefore once cherished birth of a daughter became nightmare.

During the pre-medieval $\left(3^{\text {rd }}-12^{\text {th }} A . D\right.$. $)$ and medieval $\left(12^{\text {th }}\right.$ $16^{\text {th }}$ A.D.) era the status of women seen further deterioration and they were considered as equal to Sudras(the untouchable, lowest of the all four Hindu Castes).
Dependence of woman on her husband or other male relatives became a distinctive feature of the time. Hindu women were forced to be inactive politically, socially and economically except for those engaged in farming and weaving. This inactivity can be seen as a tool to their subordination. Polygamy further strengthened the subordination of women. Social evil of female infanticide also existed in medieval Hindu Culture. Only a son had the privilege to perform the Shraddha Samskara for the peace of his dead parents in afterlife. Hence daughters were thought to be of very little use in this life or the other. Dowry system became a common phenomenon. The birth of girls became a nightmare. Child marriage for girls prevailed. Widow Remarriage was prohibited. While there are no reference of Sati custom in Vedic period and only a few in post-vedic period, this evil custom came to vague during that time.

Hindu women in Colonial period were subordinate to men and were dependent on their men for everything, moreover the religious traditions justified this subordination. Social evils such as sati, child marriage, female infanticide, denial of female education right, suppression of women and dowry flourished unchecked. This situation faced severe criticism from the colonial authorities and initiated some reforms. This period saw some dedicated Hindu social reformer and free thinkers, Raja Ram Mohan Roy and Ishwar Chandra Vidyasager are most prominent. While the former pressurized the British Govt. and succeeded on enacting "Sati Prohibition Act of 1829", the latter had a big hand in the enaction of "widow remarriage act of 1865 " and started many schools for women. There were a number of similar progressive pieces of legislation during the British period, prominent among them are Child Marriage Restraints Act of 1829, ban on Female Infanticide 1870, Native Marriage Act II 1872, Married Women's Property Act III 1874, Abolition of Devdasi System 1929 etc. There were many more social reformers and freedom fighter (Dayananda Saraswati, Swami Vivekanand, Anni Besant, and Mahatma Gandhi etc.) during this period who directly and indirectly voiced for the cause of women. After the independence of this Subcontinent the status of Hindu women started to change little by little. Both structural and cultural changes started to provide equal opportunities to women in education, employment and other factors.

\section{III.EQUAL STATUS?}

We cannot argue upon the fact that, during Vedic period between man and woman total equality prevailed. However, from the available sources it can be inferred that, quite liberal attitudes toward women did exist during the early Vedic period. The Rigveda says, "The wife and husband, being the equal halves of one substance, are equal in every respect; therefore, both should join and take equal parts in all works, religious and secular." (Sarda, 1917) During Vedic age women had importance and received due respect in the society. Receiving similar education they participated in philosophical debates with men as well.

Published By:

Blue Eyes Intelligence Engineering

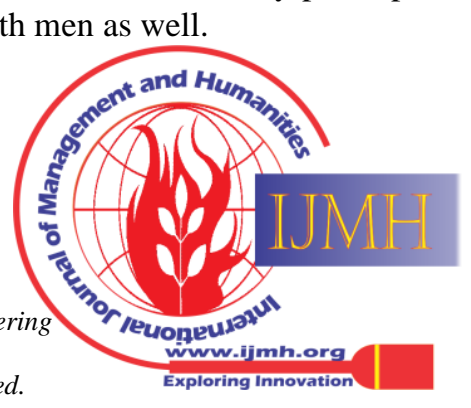


They also performed Upanayana Samskara and were taught the holy mantras of the Vedas. Some were Brahmavadinis', women who devoted their lives to scriptural study, expounded the Vedas and wrote some of the Vedic hymns. (Altekar, Education in Ancient India, 1944) Women of the Kshatriya (warrior) caste were taught warfare from an early age their childhood. Hindu scriptures provide ample examples of female philosophers, politicians, teachers, administrators and saints. The Upanishads clearly declare that individual souls are neither male nor female, they passes through many lives, both male and female. It must be noted here that in Subcontinent too since ancient times daughters were not as welcomed as sons. The latter were preferred to the former even in the Indo-Iranian age. (Geieger, 2010 ) The case was no different in the Vedic Period. The Atharvaveda contains charms and rituals to ensure the birth of a son. But that certainly doesn't imply that daughters were unwanted, one of the early Upanishads recommends certain ritual for householder to ensure the birth of a scholarly daughter. It is true that this ritual didn't become as popular as the Purusavana one. Whatsoever in cultured circles scholarly daughters were regarded to be the pride of family. There appears no question of female infanticide. It has never been accounted in Vedic scriptures that women hold inferior status than men. We can get an overall idea of the post-Vedic social structure from the Brahmanas, the Upanishadas, the Aranyakas and the great Epics of that period. The once enjoyed respectable status of women started to deteriorate during the later Vedic period. But during the age of the Dharmashastras the status of women reached to an all-time low positon. The Dharmasastra scriptures such as Manusmriti (Laws of Manu) and Yajnavalkyasmriti (Laws of Yajnavalkya) written in Sanskrit proved to be the major antecedents for such deterioration. No sense equality or justice prevailed in these laws. Patriarchy became very powerful during this time and it began to restrict the activities of women. Manusmriti states "By a girl, by a young woman, or even by an aged one, nothing must be done independently, even in her own house. In her childhood a female must be subject to her father, in youth to her husband, when her lord is dead to her sons; a woman must never be independent."(Manu Smriti 5:147-8) Women were seen as objects that invoked temptation and as hindrance in their journey toward spiritual advancement. Both in family and society their position became very low. Child marriage was encouraged and widow remarriage was prohibited by the law givers. Gradually woman began to be considered to be a burden because the male counterpart had to provide for her altogether. Being incapable to perform religious rites as Shraddha Samskaras for the well-being of the departed parents, she was considered as being of little use. Hence the birth of a daughter became more and more unwelcomed with the passing centuries. At some point the birth of a female child was considered a sign of misfortune for a family. The family which rejoiced at the birth of a female calf mourned after the birth of a female human child that is the irony. After the above discussion it can be ascertained that the subjugation, humiliation and subordination of women are the contexts of a later period, Hinduism of
Prevedic and Vedic era never saw such things. During that time women enjoyed certain power and due respect.

\section{IV.FEMALE EDUCATION AND CAREER}

After the above discussion we can come to a conclusion that Hindu women in Prevedic and Vedic age held an elevated position. Having education similar to that of men they freely perticipated with men in highest philosophical debates. During the Vedic period, Upanayana Samskara (the ceremonial initiation of the Vedic studies) was mandatory for girls as well, this practice must have ensured a certain amount of Vedic and literary education to all girls in the Brahmin, Kshatriya and Vaisha classes. For this matter we can look into A S Altekars' saying "Female students were divided into two classes, Brahmavadinis and Sadyodvahas. The former were lifelong students of theology and philosophy; the latter used to prosecute their studies till their marriage at the age of 15 or 16". (Altekar, Education in Ancient India, 1944) The Atharva Veda observes that "A maiden can succeed in her married life only if she has been properly trained during the period of studentship (Brahmacharya)". (Altekar, 1. The Position of Women in Hindu Civilization: From Prehistoric times to the Present Day, 1956) Not only in house but also in the Forest Universities of ancient Subcontinent coeducation prevailed. Maitreyi in the Uttararamacharita studied under Valmiki along with Lava and Kusa, the sons of Rama. Along with the Vedic mantras they were introduced to theology and philosophy. Girls were adept in fine arts like singing, dancing and painting. Education for girls was regarded quite important. There are ample and convincing evidences of female scholars in Vedic Society. Relegation of women to the position of Sudras, not eligible for Vedic studies, was a later age connotation, prehistoric age has seen lady poets composing hymns, some of which were destined to be included in the Vedic Samhitas. According to the Sarvanukramanika, Among the seers to whom the hymnes of Rigveda got revealed seventeen were women- Rishikas and Brahmavadinis. They were Romasa, Lopamudra, Apata, Kadru, Vishvavara, Ghosha, Juhu, Vagambhrini, Paulomi, Jarita, Shraddha-Kamayani, Urvashi, Sharnga, Yami, Indrani, Savitri and Devayani. The Samaveda mentions another four: Nodha (or Purvarchchika), Akrishtabhasha, Shikatanivavari (or Utararchchika) and Ganpayana. (Krishna, 2006) They were women in flesh and blood, once lived in Hindu society. The Yajurveda states, "The scholarly woman purifies our lives with her intellect. Through her actions, she purifies our actions. Through her knowledge and action, she promotes virtue and efficient management of society." (Yajurveda 20.84) Many educated women used to follow teaching career either out love or out of necessity. Sanskrit language found it necessary to coin a special word in order to distinguish them from wives of teachers. The latter who were not necessarily scholars were called Upadhayanis, but women who were themselves teachers, were called Upadhayayas.

Published By:

Blue Eyes Intelligence Engineering DOI:10.35940/ijmh.G1255.035721

Journal Website: www.ijmh.org

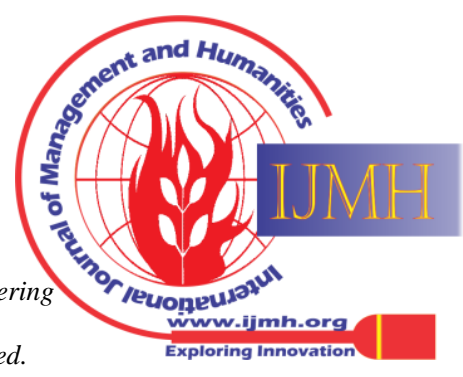




\section{The Status of Hindu Women from Antiquity to (Early) Modernity: A Downward Graph}

(Altekar, Education in Ancient India, 1944) Female teachers must have been fairly numerous in society; otherwise an altogether new term would not have been coined to designate them. It may be stressed here that the tradition of lady scholar is known to the Puranas as well; Bhagavata Purana for instance, refers two daughters of Dakshayana as experts in theology and philosophy. (Altekar, 1. The Position of Women in Hindu Civilization: From Prehistoric times to the Present Day, 1956)

An intent study of the history of female education in Hindu culture, shows that there has been a close relation between education and marriageable age of girls. With the reduction of marriageable age, education right of women was curtailed. Girls could remain unmarried till the age of 16 , dawn to about the $3^{\text {rd }}$ century B.C, the period before marriage was to some extent enough for impartation of basic education. The beginning of Christian saw pre-puberty marriages to come into vogue, thereby the time before marriage to impart education got decreased. That was a serious blow to advance studies that could not possibly be finished before the age of 12 or 13, the new marriageable age. (Altekar, Education in Ancient India, 1944) Even the initiation ceremony (Upanayana Samskara), so necessary for endowing woman with proper Aryan status, was first reduced to mere formality then dropped out altogether.

By $8^{\text {th }}$ and $9^{\text {th }}$ century A.D. marriageable age for Hindu girls was lowered to 9 or 10 , therefore girl's education faced a death blow. This put an end to any education worth the name; they couldn"t even recite the hymns of daily prayer. During the medieval foreign rule Hindu society was prejudiced against female education; the prejudice went so far that it was believed that a girl taught to read and write would become widow at an early age. The literacy rate among Hindu women had reached to nadir by about 1850 A.D. In 1929AD, a legislation was passed fixing 14 as the minimum marriageable age for girls, this has been raised to 18 in 1955 AD. This rise of marriageable age helped a great deal in female education. Hindu women enjoyed total education right in the Vedic period. How can we possibly say that Hinduism has robbed its female adherents every right to education, while a large number of verses of prominent Hindu scriptures have been the composition of the female Rishis.

\section{V.PROPERTY RIGHT, INHERITANCE AND FINANCIAL INDEPENDENCE}

Leaving behind the state of food gathering and hunting during Vedic period the participation of women in production process found to be necessary; therefore they held an honored position. Husband and wife being called Dampati during that time is indicative of the society in which relations between the sexes were based on reciprocity and autonomy in their respective spheres of activity. The basic production unit was family and home was the place for production as spinning and weaving were done here. Female members of the family worked hand in hand in the agricultural with the male counterpart. Wife had a say on the financial matters of a household.

Now the question is, could women become economically independent as a result of their training? A. S. Altekar viewed this way, "Those who followed the medical or the teaching profession could of course become economically self-reliant. The same was the case with the singers and dancers. For ordinary women spinning and weaving were of great help in the time of difficulty." (Altekar, Education in Ancient India, 1944) Many historical accounts approve Altekar's standing. For example, the Arthasastra of Kautilyan (assigned to 2nd century B.C.) stressed upon the fact that the state should be providing special facilities to women in destitute in order to enable them to earn a living by spinning. (Kautilya, 1961) Hence it can be said that Hindu women of Vedic period were financially secured, they were even allowed to work outside their household. They contributed to the family income and their contributions inside and outside household were recognized. They exercised power, if not fully equal, it was in the closest proximity. It might seem surprising to hear that Hindu women once enjoyed property right, as till today Hindu woman in our country do not get any property right. During Vedic age unmarried daughters used to get a portion of fathers property. In the absence of a son daughter had full legal right on the property of her father. Upon the death of mother property was equally distributed among sons and unmarried daughters. But the case was different for married daughter, they didn't get any share in father's property. As dowry a portion of the ancestral property used to be given to her, which turns out as her own property, namely Stridhana. As a wife, woman had no direct share in her husbands' property. A widowed mother received some share, only if she had borne a male heir. With the end of later Vedic age(c 200AD), Dharmashastra age began along with the deterioration female status. This age also saw the exclusion of woman from both economic and religious sphere. The financial independence and property right women once enjoyed in the society started to wane; they began to be treated as property themselves. Dharmasatras' such as Manusmriti and Yajnavalkyasmriti worked as antecedents to such deterioration. It is found in Manusmriti that "A wife, a son and a slave, these three are declared to have no property, the wealth which they earn is for him to whom they belong" (Manu Smriti 8.416). They lost their freedom to work outside household, thereby their work within household lost recognition. In Medieval period, Women had no right to have property or inheritance. During marriage a portion of father's property was given to the groom as dowry, girls had no share in that. Married woman had no right over her husband's property; even a widow had no share in her late husband's property; if she had borne no male heir, then her and her daughters misery knew no bound, property of her late husband were handed down to the closest male relatives, such as brothers, nephews etc. This condition went on till the $19^{\text {th }}$ and $20^{\text {th }}$ century. By enacting some female property act in late $20^{\text {th }}$ century, countries with Hindu majority population like India could ensure property right for some upper class women, but this had no effect to the life of poor and uneducated women.

Published By:

Blue Eyes Intelligence Engineering

\& Sciences Publication

(C) Copyright: All rights reserved.

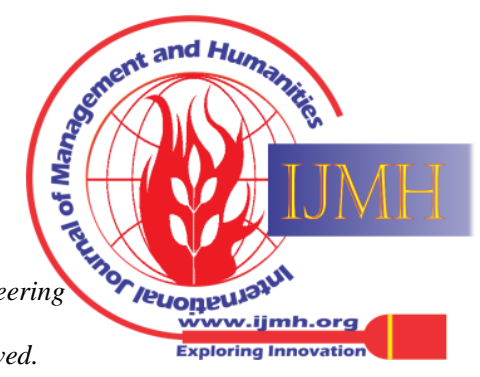


Countries like Bangladesh, where Hindu people consists only $8.5 \%$ of the total population (Official Census Results 2011, page xiii), done close to nothing to ensure the property right of Hindu women. Many a number of people blame Hinduism as a religion which has given no property right to woman; deprived woman economically. They are ignorant of the fact that Hindu woman during Prevedic and Vedic period enjoyed full property right and working right.

\section{VI.POLITICS, ADMINISTRATION AND WARFARE}

Hindu scriptures of an early age show evidences of female politician, administrators and valiant warriors. They are seen frequently associating themselves with folk assembles and actively participated in their deliberations. Vedic literature shows that women had a say in both state politics and administration. The Rigveda clearly proclaims, "the entire world of noble people bows to the glory of the glorious woman so that she enlightens us with knowledge and foresight. She is the leader of society and provides knowledge to everyone. She is symbol of prosperity and daughter of brilliance. May we respect her so that she destroys the tendencies of evil and hatred from the society?"( Rig Veda 1.48.8 ) Atharvaveda states that "Women should be valiant, scholarly, prosperous, intelligent and knowledgeable; they should take part in the legislative chambers and be the protectors of family and society. When a bride enters a family through marriage, she is to rule there along with her husband, as a queen, over the other members of the family." (Atharva Veda 14.1.43-44) Likewise other factors, women participation in political arena faced a death blow with the end of Vedic era. They had no say in the state and political factors. Their household became their world, the bird of their free thinking lost its wings. The mind which used to think about state administration, concentrated on the administration of household. Although the trend of teaching Kshatriya girls warfare went on, they were only allowed to lead an army or join one in the absence of husband or father. Rajput princesses being adept in the use of the sword and the spear is a known fact. There are numerous examples of queens or princesses leading an army or administrating a state in the hour of need. Kurmadevi, a queen of king Samarasi is known to take over the administration of her husbands' kingdom on his death and repulsed the attack of Kutub-ud-Din. Javahirdevi, a queen of Rana Sanga died fighting in her attempt to save Chittor after her husband's demise. The name of queen Laksmibai of Jhansi requires no introduction, who because of her valor, bravery and sound generalship excited the admiration of her opponents, the British army.

\section{VII.SOCIAL STATUS AND RELIGIOUS RIGHTS}

From ancient to modern age the status of Hindu women has gone through several changes, mostly from higher to lower status. Therefore it can easily be said ever fluctuating status of Hindu women. The social and religious life of Hindu woman has seen no different scenario. Historically speaking, the status Hindu woman have seen both the stages of liberation and subjugation. At times she has been seen as the representation goddess Laxmi at times she has been seen as a sign of misfortune. Seclusion of women was unknown in

the Vedic times. On festivals and other social celebrations women participated without any reserve. On festive occasions like tournaments girls perticipated with all their might and gaiety. Hindu women during that time enjoyed property right and were allowed to remain unmarried, living with their parents and brothers till the end of their lives. Atharvaveda points out that to girls could remain with their parents till death. They lived freely and in the case of marriage they had decisive voice in husband selection.

A hymn in the Rigveda says "the woman, who is of gentle birth and of graceful form, selects among many of her loved one as her husband." (Altekar, 1. The Position of Women in Hindu Civilization: From Prehistoric times to the Present Day, 1956, p. 126 ) There are numerous evidences of Svayamvara(girls selecting their own husbands) in the Ramayana, the Mahabharata and other great epics. The religious rituals and sacrificial rites associated with household used to be performed by both husband and wife. The offering and adorations presented to gods were done by both husband and wife also. The great epic Ramayana mentions an incident of Rama, the king of Ayoddhya, not being able to perform Asvamedha Yajna(a ritual performed by a king with a vision of expanding territory) due to the absence of his wife Sita. The evil custom of pre-medieval and medieval period, 'Sati' (Self-immolation of Hindu widow on her husband's pyre) was unknown to the Vedic India, as it has no reference in Vedic literature. None of the three wives of King Dasharatha performed sati in Ramayana, nor did the wives of king Shantanu, king Vichitravirya, king Pandu in Mahabharata. In must be accounted here that there was a custom of wife lying beside the pyre of dead husband, but then she was asked to come down. The Atharvaveda however shows that "it was customary for the widow to lie by the side of her husband's corpse on the funeral pyre; she was however asked to come down, and a prayer was offered that she should lead a prosperous life enjoying bliss of children and wealth". (Atharva Veda 13.2.1)There are ample evidences that present, that widow remarriage was not only allowed but also practiced, "Rise up woman," so runs a hyme of the Rigveda "thou art lying by one whose life is gone, come to the world of the living, away from thy husband, and become the wife of him who holds thy hand and is willing to marry thee."(Rig Veda 10. 18.8) After Vedic age, Dharmashastra age began along with dark days for Hindu women. Dharmashastra writers such as Yajnavalkya and Manu are not very famous for their attitude toward women, their Smriti writings Yajnavalkyasmriti (laws of Yajnavalkya) and Manusmriti (laws of Manu) written in Sanskrit worked behind such deterioration. The complete codes of Manu and Yajnavalkya lay down the rules which have to be observed by persons in the course of their life. The social customs and traditions which were reinforced by the law givers degraded women. During that time girls Upanayana Samskara came out of practice, their education became optional factor.

Published By:

Blue Eyes Intelligence Engineering

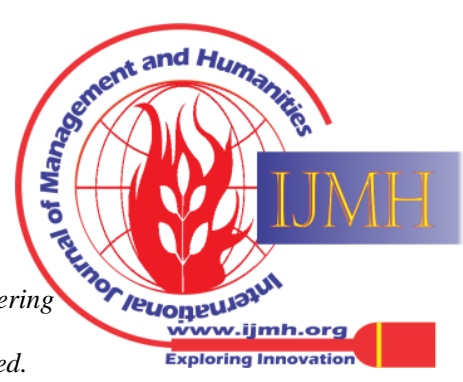




\section{The Status of Hindu Women from Antiquity to (Early) Modernity: A Downward Graph}

Manu relegates woman to such a subservient position that he preached self-negation as the highest ideal of a wife. She was asked to serve and worship her husband even if he is not a person of all virtue and character. Since service and worship of the husband are the primary duties of a wife, by so performing she can hope to attain heaven. Manu advances the extreme view that "the wife's marital tie or duty do not come to an end even if husband were to sell or abandon her."

(Altekar, 1. The Position of Women in Hindu Civilization: From Prehistoric times to the Present Day, 1956, p. 53) References from Manusmriti are used by both fundamentalist and liberalist, while former has the objective of subduing women, for the latter it was positioning women in a higher status. Many scholars assumed that original Manusmriti has been corrupted. Along with the verses which subdued women, there are some points where Manu asked to honor women.

At one place Manusmriti stated, "Women must always be honored and respected by the father, brother, husband and brother-in-law who desire their own welfare, and where women are honored, there the Gods are pleased. But where they are not honored, no sacred rite yields rewards." (Manu Smriti 3.56) The Hindu Epics, Ramayana and Mahabharata portrayed women as obedient wives, as Sita (wife of Rama, the king of Ayoddhya) and Draupadi (wife of five Panadava brothers), who suffered acutely but never complained. Sita and Draupadi were shown as role model for other women, as they were expected to bear all sufferings but still remain obedient to their husbands'. In those scriptures there were no such thing as equality between man and woman. The social status once enjoyed by Hindu women was taken away from them, but not by religion, by the people who call themselves religious. Hence it is not advisable to blame Hinduism for snatching basic human rights from women and making them social handicap.

\section{VIII.LIMITATIONS OF RESEARCH}

Along with other minor ones I had two major limitations in my work. First one is, in my attempt to cover a huge timeline I had to keep my discussion brief to make it a good read. If I had taken the later modern period and contemporary period too, the graph might have roughly taken a U shape; but the research paper would have exceeded the word limit. Hence there undoubtedly remains the field of detailed and further discussion, hypothesis can be made from each of the eras or sectors. The female education part deserves much more justice, where I would like to do further research. The second one is that the researches on religious factors are much more sensitive than others. In my pursuit of writing this paper I had to be over cautious about what I put into writing, otherwise it might hurt the sentiment of a certain religious community.

\section{IX.CONCLUSION}

Observing a certain historical timeline and saying that Hinduism has only subdued and suppressed women, would be a mistake done by many a man. As far we go back in the history the condition of Hindu women gets better. While the Hindu scriptures of later period sometimes subordinated women, early scriptures showed no such thing. As I have accounted above, Hindu women enjoyed certain status during the Vedic period. They had almost equal status as men, they had rights of education, property and enjoyed financial independence. During that time they were even politically active; actively participating in the administration of state. The subjugation, humiliation and subordination of woman are the contexts of a later period, Hindu Religion of Prevedic and Vedic age never saw such things. During that time women enjoyed certain power and due respect. Therefore it can strongly be said that the status of Hindu woman from prevedic to early modern period resembles a downward graph.

\section{REFERENCES}

1. Altekar, A. S. ( 1944). Education in Ancient India. Benares, India,: Gyan Publishing House.

2. Altekar, A. S. (1956). 1. The Position of Women in Hindu Civilization: From Prehistoric times to the Present Day. Delhi, , India: Motilal Banarsidass Publishers Private Limited.

3. Bose, P. N. (1990). Civilization Through The Ages; . New Delhi, Mittal Publications;.

4. Manusmriti: The Law of Manu. (1991). (W. a. Doniger, Trans.) London United Kingdom: Penguin Books.

5. Durkheim, E. (2010). The Elementary Forms of the Religious Life, Translated by , Oxford World's Classics. (C. Cosman, Trans.) Oxford, England : Oxford University Press.

6. Geieger, W. (2010 ). Civilization of Eastern Iranians: With an introduction to Avesta Religion. Whitefish, Montana: Kessinger Publishing.

7. Goel, D. M. (2018). The Sacred Feminine in Hinduism:The Divine as the Mother. Insight .

8. Kautilya. (1961). Arthasastra. (V. Narain, Ed., \& R. Shamasastry, Trans.) Mysore: Mysore Printing and Publication Company limited .

9. Krishna, N. (2006). The equals of men. India: New India Press,.

10. Sarda, H. B. ( 1917). Hindu Superiority. .Scotland,: Scottish Mission Industries.

11. Tiwari, K. N. (1987). Comparative Religion. New Delhi, India: Motilal Banarsidaas Publishing House.

12. ( 2015). Millennium Development Goals: . New Delhi, India: Indian Country Report.

13. www.sacred-texts.com/hindu.html Retrieved at 20/22015. (n.d.).

14. http://www.irjmsh.com, Retrieved-15/2/2015

15. http://www.sacred-texts.com/hindu.html Retrieved at 20/22015

16. http://www.ancient.eu/The_Vedas/atharva.html Retrieved 29/1/2015

17. "Official Census Results 2011 page xiii" (PDF). Bangladesh Government. Retrieved 17 April 2015

18. https://www.ancient.eu/The_Vedas/yajur.htm

19. https://www.loc.gov.>Icwa0002821

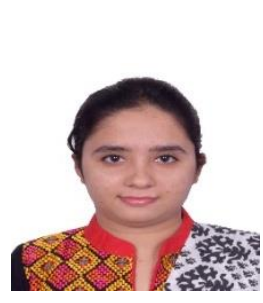

\section{AUTHORS PROFILE}

empowerment and female education.

Sadia Afrin, is currently working as a full time lecturer in the Department of World Religions and Culture, University of Dhaka. She has completed her BA and MA from the same department. From her undergrad level Sadia had grown a keen interest in the status of women in different religions. She has other works focusing on views of different religions regarding woman 